University of Louisville

ThinkIR: The University of Louisville's Institutional Repository

Electronic Theses and Dissertations

$12-2010$

\title{
The gorilla and the cuttlefish.
}

Nick Karl 1982-

University of Louisville

Follow this and additional works at: https://ir.library.louisville.edu/etd

\section{Recommended Citation}

Karl, Nick 1982-, "The gorilla and the cuttlefish." (2010). Electronic Theses and Dissertations. Paper 726. https://doi.org/10.18297/etd/726

This Master's Thesis is brought to you for free and open access by ThinkIR: The University of Louisville's Institutional Repository. It has been accepted for inclusion in Electronic Theses and Dissertations by an authorized administrator of ThinkIR: The University of Louisville's Institutional Repository. This title appears here courtesy of the author, who has retained all other copyrights. For more information, please contact thinkir@louisville.edu. 


\section{THE GORILLA AND THE CUTTLEFISH}

By

Nick Karl

B.F.A., University of Louisville, 2007
A Thesis

Submitted to the Faculty of the

Graduate School of the University of Louisville in Partial Fulfillment of the Requirements for the Degree of

\section{Masters of Art}

Department of Fine Art

University of Louisville

Louisville, Kentucky

December 2010 



\section{THE GORILLA AND THE CUTTLEFISH \\ By}

Nick Karl

B.F.A., University of Louisville, 2007

A Thesis Approved on

December 1, 2010

By the following Thesis Committee

Thesis Director 


\section{ACKNOWLEDGEMENTS}

I would like to thank my professor, Jim Grubola, for his wonderful insights and thought-provoking conversations during critiques, as well as the opportunities to broaden my horizons in the art world. I would also like to thank Mark Priest for his amazing perspectives and constant support, which has allowed me to see my work from different angles. Also, I would like to thank Dr. Michael Johmann for his inspiring class discussions, opening my eyes to the world that surrounds me, and sheer passion for teaching. It was through the guidance and dedication of these three thesis committee members that I have been able to become the learned person I have become today. Finally, I would like to thank my family, Jonathan Karl and Susan Karl, Robin and David Crosier, Shayne and Ben Brill, and Natalie Karl for their selfless support, understanding, and all around awesomeness. 


\section{ABSTRACT \\ THE GORILLA AND THE CUTTLEFISH}

\section{Nick Karl}

December 1, 2010

The new work I have developed while pursuing my Masters in Art at the University of Louisville is strongly based on the narrative. I have always used the imagery in my work as social commentary. The stories and images I develop are to be viewed as a window on the world through my eyes, but for the first time I have focused on one clear concept. In this case, questioning how we developed from a group of hunter-gatherers scouring the land for survival, to modern consumers, destroying the world around us.

In order to facilitate this narrative, I wrote a very short fable-like story entitled The Gorilla and the Cuttlefish, and then set about to illustrate it. Using chalk pastels, I cover the page with a lush variety of colors, patterns, and figures. I want fill every bit of the paper - moving the viewers' eye constantly around the page - but also creating a holistic composition, which allows the viewer see the complete story in each piece. My goal is to make the viewer look upon what at first seems like a fanciful and bizarre world, but with closer investigation find it is anything but. 
My work is to be seen as my personal viewpoint of history and modern life how we as humans sprang from nothingness into the socially diverse creatures we are today; how our drive to conquer all around for the last 12,000 years has slowly destroyed our only source of life. I am not an environmentalist or activist, but rather a realist. I don't see myself as better than anyone else in the world, but I'm also an active participant in the very destruction I speak of. We have just come to a point in our culture where acceptance is the new norm, and ignorance is bliss. I feel as an artist it is my job to illustrate how apathy and man's superiority complex has led to unfortunate, but not unexpected, consequences. 


\section{TABLE OF CONTENTS}

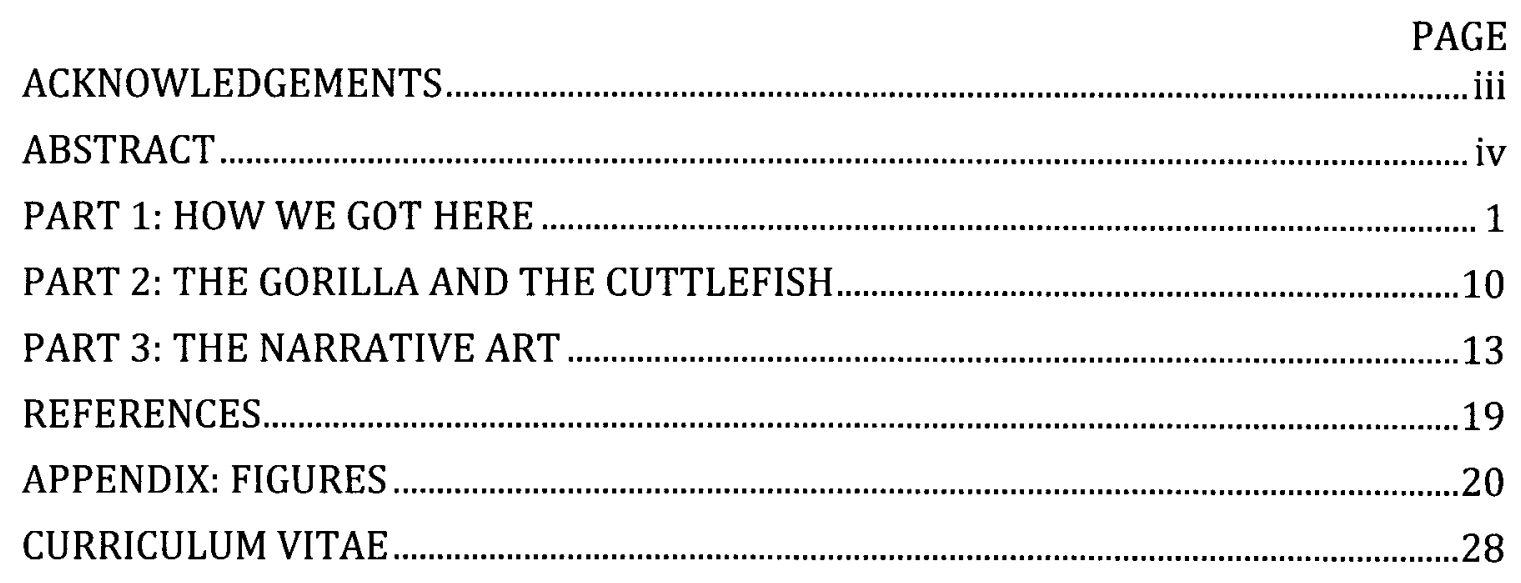




\section{PART 1: HOW WE GOT HERE}

The long journey human beings have had on this planet is nothing to be scoffed at. Fossil evidence shows that Homo sapiens have walked the earth for at

least 200,000 years. In the last 12,000 years, we have gone from what is considered to be an unsophisticated group of hunter-gatherers to explorers of the universe. This amount of time is merely a speck of dust considering all that had come before us, before our rise to become the most dominant species to have ever walked the 4.5 billion year old planet.

However, in our ever-continuing quest to understand the world around us, human beings have developed one devastating character flaw - we don't obey the laws of nature that were in place long before we learned to sow the first seed. Human beings have forgotten that the existence we lead before the agricultural revolution was a balanced and fair, although somewhat harsh, way of life. Once we learned that we could master the environment for our continued growth as a species, we lost sight of what an ethical life on this earth was meant to be. Humans, being blessed with conscious thought, have made a faulty assumption. This world was made for us, therefore it belongs to us, and we should reap the benefits. The problem that lies here is that our conquest of the world's resources is propelling us faster and faster towards our downfall. In spite of all of the amazing 
things we have accomplished, we haven't found the will to stop devastating the world - or repair the damage we have already caused. The Worldwatch Institute of Washington, D.C., an independent environmental research organization, has been publishing a review of the declining condition of the global environment for the last 25 years. For the most part, their forecast is grim.

Much of the deterioration can be traced directly to human activities: urban expansion has led to species loss; industrial manufacturing has led to air pollution; factory farming to water pollution; and chemical agriculture has poisoned soil. Our rising population numbers, increasingly efficient technologies, and consumption rates beyond this planets capacity compound these problems.

The agricultural revolution was our "genesis," our fall from grace if you will. We ate from the tree of knowledge, and our punishment was to be tillers of the soil. We believed we had accomplished greatness by never having to go hungry again, when in fact we had initiated a sequence of events that would forever keep us pressing forward towards bigger and better things, not realizing that this path would lead to our own destruction. Human beings kept striving for new innovations and technologies, which lead us into our modern world. This world consists of a selfinvolved, consumer-based society, where we would rather turn on a television and eat junk food than consider our futures.

One could easily think of human beings as the most dominant species on earth and, because we possessed the ingenuity to control nature, thus had the right to live as we please. However, who is to say that we have taken the correct path? 
Why were the ill-gotten gains of the agricultural revolution thought to be a better way of life than that of a hunter-gatherer society?

The first and most valid argument is that we were now able to control our food source, and live a life of stability rather than constantly in a threatened state of existence. Having a constant means of sustenance meant we could expand our race, cultivating the land around us, and move forward into a brighter tomorrow. This idea of controlling our world has one major drawback. This act is not consistent with fundamental laws that occur in the rest of the environmental community.

In order for us to expand our reach over the globe, we have exterminated all competitors. In the wild, animals defend their territories and hunt the land, yet they never hunt competitors simply to get them out of the way. If that were the case, no competitors would exist. There would only be the strongest species at each level of competition. The human race has embarked on a path to do just this, eliminating all that would oppose our will, whether it animal, or our own kind.

As for the latter, the agriculturalists would deny human competitors, such as hunter-gatherers and herding cultures, access to these new food resources. A mentality had arisen that every inch of this planet belonged to them; so all of it must be cultivated. Anyone who obstructs our path towards control is to be struck down and doomed for extinction. As for the animal world, denying competitors access to food is never done with malice. They might fight one another for nourishment, but there is never an ulterior motive behind such an act.

The most pressing issue that agriculturalists face is the population explosion. This resulted from the lack of competitors and the constant need to increase food 
supplies. This leads to a simple paradox that was coined by Peter Farb, an American anthropologist and ecologist:

"Human beings now found themselves on a treadmill from which to this day they have not been able to get off. They are still plagued by the basic paradox of food production: intensification of production to feed an increased population leads to a still greater increase in population." (Farb, 121)

The need for increased food production was the major cause of drastic changes in political, social and economic life. Without it, complex societies would never have developed. As we adapted to the ways of food production, new attitudes developed towards material objects and possessions. Sharing of goods was restricted to family circles, and the idea of "owning" things became a sign of true wealth. Gone were the ideas of sharing food, raw material, and lands as the huntergatherer tribes before them lived. New behaviors developed among our ancestors, such as possession for exclusive use, constantly gathering and defending territories, and the idea of inheritance. All of this in turn caused the social structure of human societies to shift. The differences in wealth, power and status among men became a prominent factor in how societies interacted. This is the exact point where people were divided into the rulers and the ruled, the haves and the have-nots.

It is though this sweeping change in the social dynamic of human beings that technological innovation began to spring forth. Highly specialized occupations arose in these early communities, all based around the innovation of food production. Technological breakthroughs such as agricultural implements, spinning and 
weaving, ceramics, metallurgy, wheeled vehicles, calendars, and record keeping are all the children of the agricultural revolution.

The condition of human beings on this planet changed so greatly by the advent of commercial food production that it would have been impossible to go back to the simple hunter-gatherer existence. The power of controlling nature had too much momentum to halt it, and for what reason would the people of this time period want to do such a thing? Life was consistently getting easier as one technological breakthrough led to another. It would have been foolish for one not to embrace such a forward-moving culture. It is only when one looks at the future society this would eventually produce, that they must reconsider; that for all of our magnificent achievements of the past, there were unforeseen consequences that we must now endure. What once seemed like the right thing to do can, in hindsight, come back to haunt you.

Of course, there is no way to blame our ancestors for their accomplishments. Who wouldn't want to live a life that was made simpler, as new methods and inventions for dealing with your surrounding environment develop around you? The problem is that our constant need to strive for the bigger and better has in turn began to destroy the very foundation that provides for us. As our population continually grows at exponential rates, the demand for our limited resources on earth increases in turn. This never seemed to be a serious issue until the dawning of the industrialized modern era. But only now is our planet finally beginning to show the early signs of its own demise. 
This modern world we find ourselves in is a consumer-based society. In this throwaway culture people for the most part are only concerned with themselves, and their own immediate future. All the while they willingly and ignorantly turn a blind eye towards impending doom. As the demand for practical and impractical products increases, there is a swelling ecological footprint left behind it. Material extraction, production, distribution and waste disposal all have great ecological costs - many of which threaten our existence.

The environmental impact of consumerism is astounding. Almost half of the earth's forest cover is gone, and as mechanical harvesters become more efficient the pressures on the remaining forests are only going to increase. Increased deforestation leads to loss of habitat, in turn causing a loss of species. The loss of animal life is not only caused through the modification of their habitats for human activities, such as agriculture, logging and suburban sprawl, but through the use of hydroelectric dams, irrigation channels, sewage, disposal, and industrial waste.

The increasing farmland use for food production and livestock also carries with it a severe cost to the environment. Soils are systematically exterminated of threatening insects, bacteria and fungi, leaving the soil sterile. Irrigation channels lower major river systems, causing competition between water for human use and industrial facilities. Pesticides have toxic effects on not only the environment but also in human tissues, as they seep into our soil and groundwater.

Last but not least, the issue of global climate change is at the forefront of our ecological dilemma. Industrialized countries are responsible for $75 \%$ of global carbon emissions. The chief contributor is carbon dioxide emissions from the use of 
automobiles. There are an estimated 600 million motor vehicles in use on the planet today. The consumption of fossil fuels for automobiles and other industrial uses has been linked directly with atmospheric destabilization, and the cause of violent swings in the global climate patterns.

All of the above stems from the growth of the consumer society that we live in today. Often going far beyond their actual needs, most consumers indulge in products that are made for personal pleasure. We use our leisure time spending money, believing that owning things is the primary means to happiness, which in turn is assumed to be our primary objective in life. The lives we lead and our very sense of identity drives the consumerism machine, and we have come to believe that by consumption, we will further our self-development, self-realization, and selffulfillment. In this consumer society, our very self-identity is based on our possessions. The consumer goods we surround ourselves with are symbols of status. We truly believe the "we are what we own" mentality, which makes us even more removed from what is actually happening in the world around us.

The average American is bombarded with over 3,000 advertisements a day. Under such a rampant frenzy of messages, it is easy to understand how one could lose themselves and become simply a puppet on strings, led towards whatever product is said to make you a "better person." Advertisers deliberately make the consumer more self-involved. They play on our emotions, our need for security, acceptance and happiness. They create stereotypes, fostering greed, status envy, anxiety, and cause a sense of dissatisfaction and inadequacy. The satisfaction that we get from being consumers is only temporary, as we are beckoned over and over 
to indulge in order to satisfy our urges for some sort of self-worth. This generates emptiness within, a dull depression, our lives reduced to nothing but purchasing items for the sake of buying.

The major player behind this barrage of advertisements is the media. Most people come home from their job or school and plop down in front of the flickering screen of a television or computer. Commercial television actively reinforces consumer values, promoting consumer class lifestyles with its programming. The average person watches four or more hours of television a day. Many households leave the television on day and night. In between all of the news, entertainment, and random drivel, the advertisements and lifestyle enforcing propaganda creep into more and more hours of airtime, as well as our consciousness. Most Internet sites you visit are filled with advertisements, sometimes bordering the entire page you are browsing. It doesn't stop there, however. Pop-up advertisements interrupt you constantly. Sometimes, when you are viewing a site, the entire page will shift as you view it in order to provide even more advertisement space, forcing you to close the window before going back to the site. There is no escaping the all mighty advertisement gods. They are everywhere; constantly beckoning you to "reach out and touch someone" or trying to convince you that you truly are "loving it."

Consumerism rests on the assumption that human desires can never be met; and if there are an infinite number of ways to be dissatisfied, there are boundless opportunities to create new products in order to meet new desires. Values associated with consumerism are wrapped around the human need for security, belonging, status, and happiness. Products you purchase are meant to provide you 
with this happiness. Slogans are used over and over again, the theme always being the same. A fast-food meal, a new car, a beer; each of these things are what is required to provide the buyer with a sense of relief from the anxiety of not fitting in, from loneliness or inadequacy. This consumer ideology has become such a part of our everyday life that we no longer question or notice it.

I myself am a victim of this way of life. As I sit here and type this thesis on the newest laptop computer, I see the irony of the situation. I'm no better than any other consumer who lives in this modern world. I myself sit by and do nothing as the earth is plundered of its natural resources and poisoned by our own greed and superiority complex. I am not an environmentalist or political activist. I am simply one of the cogs in the great consumerism machine I have just described. I believe that what I am doing here is simply trying to reveal this world to myself as well as the others. I truly want to believe that most people realize what is going around them, but they have simply decided to turn a blind eye to it, believing that our society as a whole has been too brainwashed and is too scared to imagine that there is another way for us to live. I know the idea frightens me, and my pessimism makes it difficult to even fathom all of us coming together and turning things around. We can hardly control our own lives; how are we to be expected to control things much bigger than us? We put it in the hands of our governments, religions, and corporations to make the big decisions for us. We are simply marionettes, our strings pulling us whichever way desired. Lulled into a life where happiness can be purchased, big problems are not for us to worry about, and ignorance is bliss. 


\section{PART 2: THE GORILLA AND THE CUTTLEFISH}

The jungle was serene and beautiful. Fairies danced about on the breeze. The gorilla sat among the treetops, grazing at all that nature had to offer. Life was simple.

Below, tentacles emerge from the waters. Pushing the high grass and cattails aside, the cuttlefish beckons upwards. "Dear gorilla, make your way from the trees and see what I have to offer you."

Obliging the cuttlefish, the gorilla swung down the branches clumsily, plopping loudly into the cool pond. The mollusk, now fully emerged, revealed its reason for the invitation. "These are my babies," it quipped "they hold all the knowledge of the universe, and they will lead you into a new world." The gorilla smiled, revealing his great ivory teeth.

"Know this though, dear gorilla, they must be given time to hatch. Only when they have truly developed will they reveal their secrets."

The gorilla nodded understandingly, and promised to keep the cuttlefish's babies from harm's way. However, the fairies of the forest, naturally inquisitive, began to imagine that the eggs were calling out to them.

Quickly the eggs were snatched up and opened by the fairies, spewing the secrets held within them into the jungle. Chaos ensued. 
The cuttlefish lashed out ferociously, destroying all around it. The animals of the forest became fearful and began to join the destruction. The gorilla extinguished much of the wildlife himself. All the while the fairies continued opening the eggs, not comprehending that they were hastening their own undoing. The sage of the jungle, seeing the chaos, prayed to the gods for all to return to normal, but his prayers fell on deaf ears.

Yet his cry to the heavens did awaken a Phoenix. With its wings made of fire he rose above the madness, but then suddenly crashed back upon the forest floor.

A rain of burning feathers fell down upon the landscape, scorching the terrain, splitting it into chunks, and flinging it upward toward the sky. Volcanoes erupted around the jungle, their force incinerating all in their wake. The cuttlefish in great distress, expelled its ink into the waters, and what once were his tentacles became mechanized tendrils. He continued to lash out methodically, tearing down the jungle piece by piece.

The gorilla was carried away from the jungle by the cuttlefish. The sage seized an opportunity. He queued fairies for amputation of their wings. Plants, their likes never seen before, rose from the ashes and suddenly bloomed around the remaining land. Giant television screens bearing flowers began to blossom, wrapping vines around the now flightless fairies. They were to be rewired for the inevitable future.

The world the gorilla once knew had changed. It became bleak and virtually devoid of the natural plant life. Towers rose into the heavens, lights flickered in the night sky; it just somehow wasn't the same. "Too much too soon," he reflected, 
staring vacantly at his own television screen. The trash built up around him, and he let it lay. Lethargic and abandoned by all he had known, he grumbled unintelligibly as the television glare flickered across his now vapid face.

"It is what it is," he lightly muttered, as he consumed more of the processed products of his new world. 


\section{PART 3: THE NARRATIVE ART}

The story of The Gorilla and the Cuttlefish is the background needed in order to understand the artistic narrative I have created for my Masters thesis in studio arts. Broken into six separate pieces, The Gorilla and the Cuttlefish is a fable/parable that I have written and drawn in order to show my own opinion of how we came to the place we are in now; the causes and missteps that have led to the life we know today.

The process of designing each piece begins simply enough. Small pencil drawings are first created, which are the basis for the larger work (fig. 1 and 2.). The main goal of this is to develop a composition that I feel will translate well onto large paper. These small drawing are done in black and white, but as they near completion I am able to envision the color scheme, or at least some idea of what the colors in the final piece will look like. Usually the smaller drawings appear more complicated than the larger pieces, mainly because of the use of small mark making, such as cross hatching and line work to develop forms. These are unneeded in the final product, where pattern and color become the works' main aesthetic when executed in chalk pastel.

The basic plot of the narrative begins in Chapter 1: The Jungle (fig. 3.), the first drawing. The gorilla sits atop the trees, whimsical and complacent. Life in the 
jungle is untouched, unscathed, and all the animals live in harmony, compliant with the laws of nature. The fairies' queen sits in the background, watching as the cuttlefish tentacles slowly rise up from the pond below. This gains the attention of both the gorilla and the fairies, as the cuttlefish lightly coos to them and asks for their presence below in the water. It is in this piece that I establish the prevailing color scheme for the rest of the narrative, and establish recognizable patterns and figures that lead the viewer from one piece to another, creating a sense of movement as well as a backdrop onto which the rest of the narrative will play out.

The next panel, Chapter 2: The Rendezvous (fig. 4.), displays the gorilla and cuttlefish sharing the pond together, and is the first time the eggs are revealed. These eggs are representative of the hidden knowledge that the world possesses, all of which up until this point has been unknown to the creatures of the world I have created. These eggs are not to be seen as evil, but a way in which the creatures will be able to reveal all of which is available to them. There is a catch, however: They must be given the opportunity to hatch of their own accord, for if opened too early the enlightenment they possess within them will be easily misconstrued. The gorilla is inclined to let them hatch on their own as the cuttlefish requests, but the anxiousness of the faeries to have this knowledge revealed to them quickly leads to the opening the eggs. What at first seems beautiful soon turns to be anything but beautiful.

This piece can be seen as an analogy of two things: When taken from a religious perspective, this piece can be viewed as the story of Genesis from the Old Testament. The eggs replace the apple from the tree of knowledge and by opening 
these eggs we cause our own expulsion from the Garden of Eden. Or, when taken from a more secular perspective, the knowledge we received from these eggs could be seen as the very first seeds of technology being planted. The beginning of our undoing was the belief that could control the world around us. This refers back to my ideas on the role the agricultural revolution played in beginning the end for our life on this planet. I must stress that the faeries do not represent Eve being the cause of our destruction, but rather they represent human curiosity getting the best of us, and leading to our eventual downfall. It is my hope that although the fairies may be seen as female, they are first to be seen as a manifestation of the naiveté of all humans.

Chapter 3: The Explosion of Knowledge (fig. 5.) shows the uncontrolled release of the eggs' knowledge across the landscape. As egg after egg is opened by the faeries (who are meant to represent human beings' intellectual curiosity) more and more of the world begins to spiral out of control. The gorilla must now wrestle with nature, represented by the bull, in order to control the constant innovations and technologies that begin to expand over the landscape. The cuttlefish, angry at the faeries lack of control and impulsive ways, lashes out at all surrounding it. The tentacles grab at their surroundings, pulling whatever they can down into the pond. It is at this point we are to realize that the cuttlefish is meant to represent the earth, fighting back against the unbalance that it has unwittingly created. The sage of the jungle prays to the gods in the right corner of the piece, but as time goes on he realizes that there are no gods to pray to, or at least none who are willing to listen. The Phoenix rises behind him, the culmination of all knowledge, scorching upward 
towards the universe, the peak of our newfound knowledge. The Phoenix can be seen in many ways, but its representation here is to be seen as the twentieth century (and all of its destructive innovations). It is to represent the rise of industry; capitalism and consumerism; the development of nuclear weapons; and the allconsuming fire that has taken hold of the human mind's thirst for ever more knowledge.

The next panel entitled Chapter 4: The Expansion (fig. 6.), is representative of the modern age we now live in. The cuttlefish is known in nature to change shape and color in order to blend in to its environment, and this is precisely what the mollusk does. Gone are the fleshy tendrils it once possessed, replaced with mechanical arms. It has transformed into a machine. The now cybernetic cuttlefish sprays its ink into the water of the world. The representation of nature, the bull, lies dead in skeletal form, burning below the cuttlefish. The animals of the forest die off one after another, as the land is cultivated. The cuttlefish's tendrils clear-cut forests and lash down upon the remaining terrain. The sage, now realizing the god he once adored was a work of fiction, reaps the benefits of the destruction, collecting the monetary sums while those below him suffer in his wake. The climate of the world begins to change, volcanoes rise in the distance, clearing away even more of the expanse. The gorilla and the faeries are carried away into the unknown, the land they once loved so much now a fleeting memory.

The next panel in the narrative, Chapter 5: The Brainwash (fig. 7.), shows what the fate of the faeries is to be - our minds now forced into a world where we were not meant to be. Giant plants with television screens rise up around the now 
desolate land, their vines wrapping around us, holding us hostage. Our wings have been amputated, leaving no means of escape. We are plugged into the world and a new consciousness arises among us. The consumer consciousness becomes the prevailing doctrine, and we only have small reminders of what our past was like. As we are forced to endure advertisement after advertisement, product after product on a day-to-day basis, we begin to lose any real sense of happiness and humanity. Consumerism and the quest for products now dominate our consciousness and our landscape rather than trees, birds, and living beings. We now accept this for how the world works.

In the final piece, Chapter 6: The Acceptance (fig. 8.), the gorilla has conformed to the modern way of living as well. He has mutated from primate to the modern human form, embodied as a quasi-self portrait, sitting alone in a La-Z-Boy armchair surrounded by products of our consumer world, watching the same brainwashing drivel over and over. This is my representation of how I am not free of the traps of modern society that have sprung up around me. I am not a person who is an exception to the ideas that I have explained throughout my thesis; rather I am another part of the problem.

Consumerism is as much a part of my life as it is for the entire Western world. Escaping from the idea seems next to impossible to me, and I believe a lack of faith in being able to change the world rings true among most of the population as well. The "What can I do about it?" mentality has become so set within our psyche that we have given up on the idea of genuine change. Our throwaway society has led us to become a throwaway generation. We have chosen to leave it to our children to 
address the issues that are destroying our planet. We go about our lives as if nothing is wrong, when in fact everything is wrong. We have become self-involved, selfindulgent, and egomaniacal. One only has to look toward the advent of social networking to see where a simple convenience has led to social deconstruction. What began as a way to view the lives of those around us has led to an obsession of how we are perceived by others, causing self-consciousness that never should have existed. It serves only to feed our ever-growing egos, and in turn we strive toward making ourselves more desirable with the consumer products we otherwise would not need.

To bastardize Descartes, “I shop, therefore I am." Most people have accepted that owning things is the path to true happiness, which leads to acceptance, and finally, true piece of mind. At what cost does this ownership of objects come at? What final price shall we have to pay in order to gain self-worth? It has become obvious to me that the price we will pay is great. Unless great collective efforts are put forth by the world's population, the price of our greed will be our very extinction. 


\section{REFERENCES}

Barnhill, David Landis, Good Work: An Engaged Buddhist Response to the Dilemmas of Consumerism, Buddhist-Christian Studies, Vol.24 (2004) pp. 55-63

Barnstone, Tony, Technology as Addiction, Technology and Culture, Vol. 41, No. 1, (Jan. 2000) pp. 190-193

Campbell, Colin, What is Wrong With Consumerism? An Assessment of Some Common Criticisms, Anuario Filosofico, XLIII/2, (2010) pp. 279-296

Clayton, Edward, Aesop, Aristotle and Animals: The Role of Fables in Human Life, Humanitas, Vol. XXI, No. 1 and 2, (2008) pp.179-200

Eisler, Riane. The Chalice and the Blade: Our History, Our Future. San Francisco: Harper \& Row, 1988

Farb, Peter. Humankind. Boston: Houghton Mifflin, 1978

Henderson, Amy, Media and the Rise of Celebrity Culture, OAH Magazine of History, Vol. 6, No. 4, Communication in History: The Key to Understanding, (Spring, 1992) pp. $49-54$

Kaza, Stephanie, Overcoming the Grip of Consumerism, Buddhist-Christian Studies, Vol. 20 (2000) pp. 23-42

Mitchell, John F. B., Lowe, Jason, Wood, Richard A., Vellinga, Michael, Extreme Events Due to Human-Induced Climate Change, Philosophical Transactions: Mathematical, Physical and Engineering Sciences, Vol. 364, No.1845, Extreme Natural Hazards, (Aug.15, 2006) pp.2117-2133

Quinn, Daniel. Ishmael: An Adventure of Mind and Spirit. New York: Bantam/Turner, 1995 


\section{APPENDIX: FIGURES}

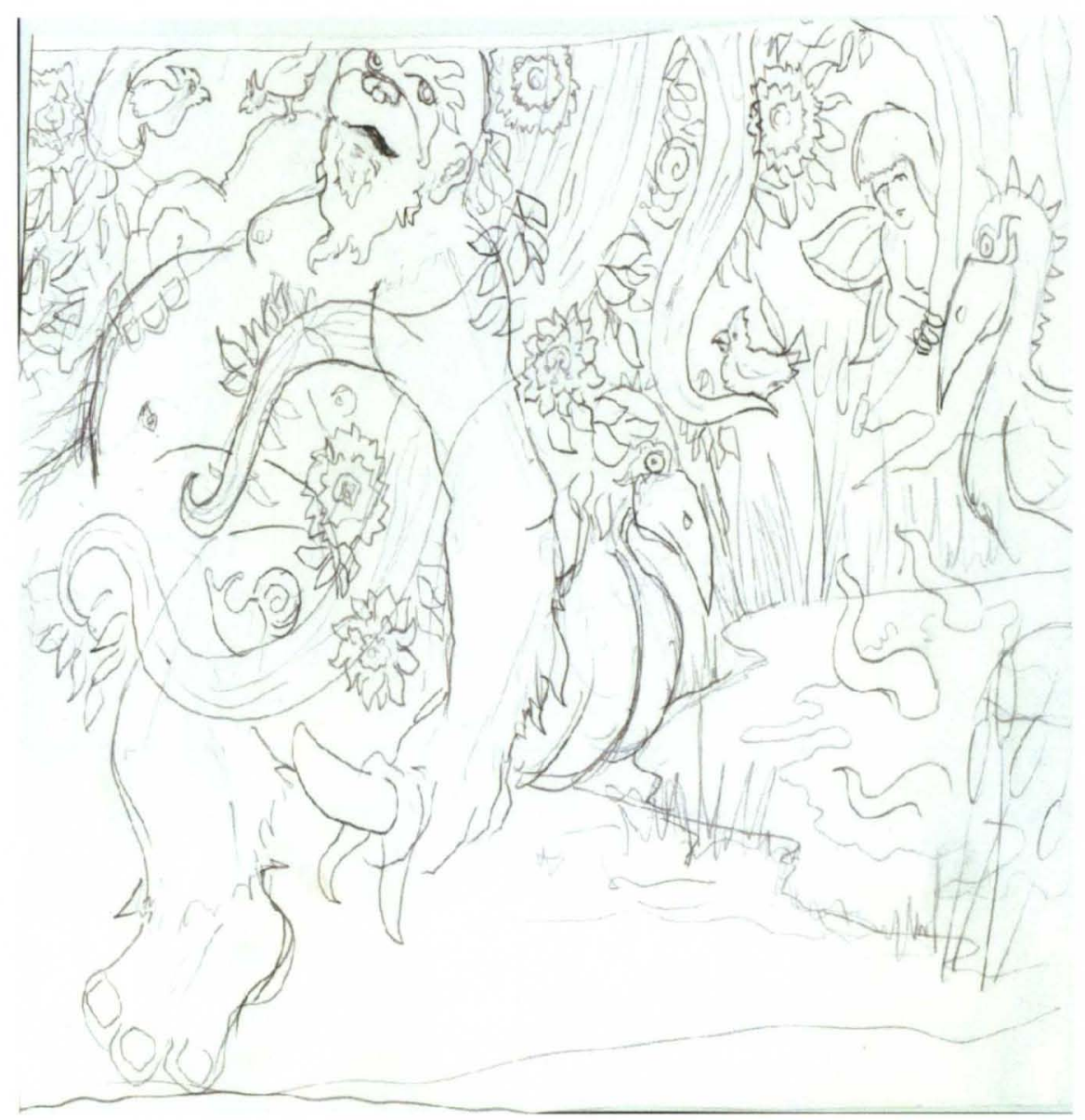

Figure 1. Untitled: Concept Drawing, Pencil and paper, 2010 


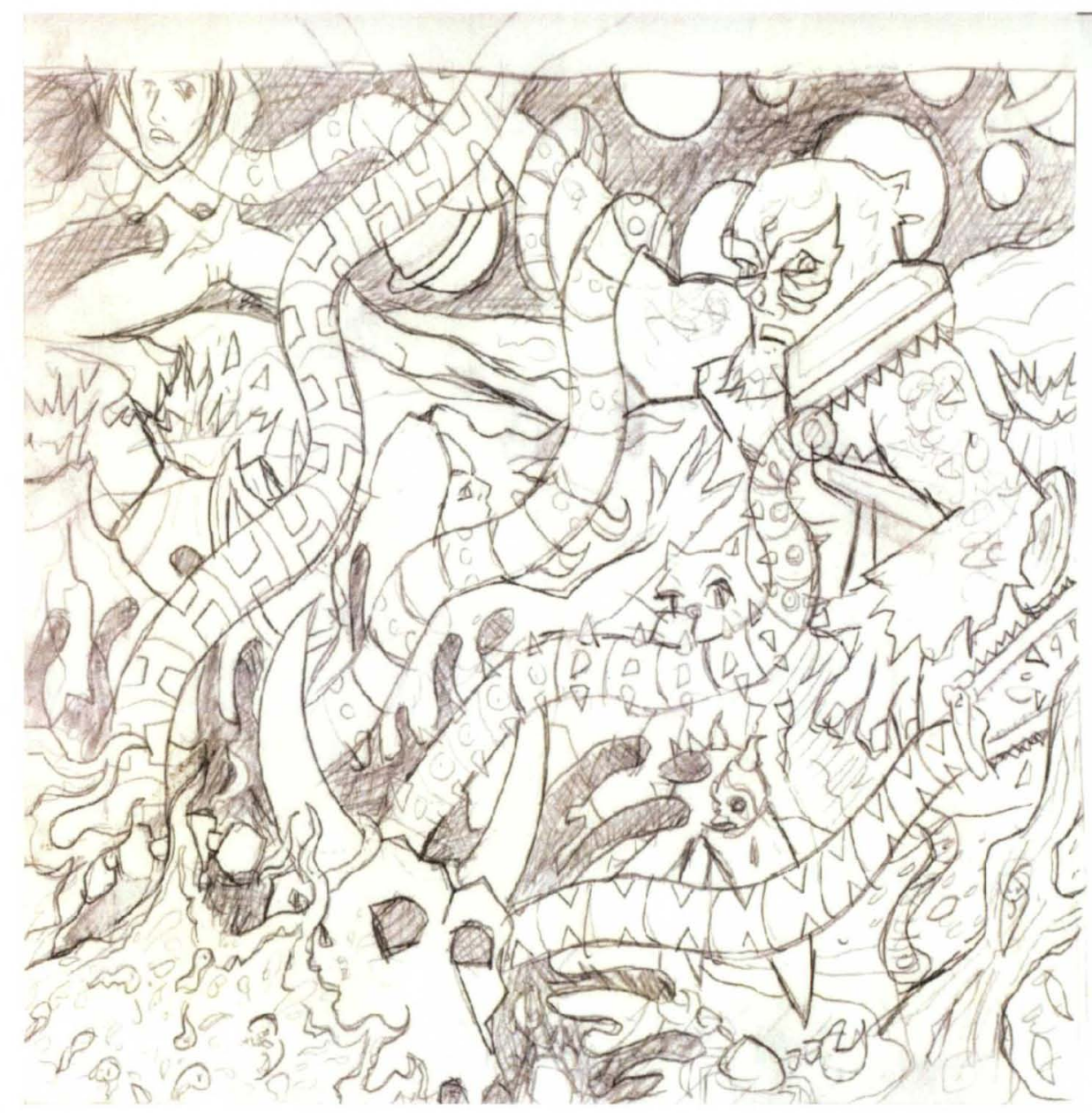

Figure 2. Untitled: Concept Drawing, Pencil and paper, 2010 


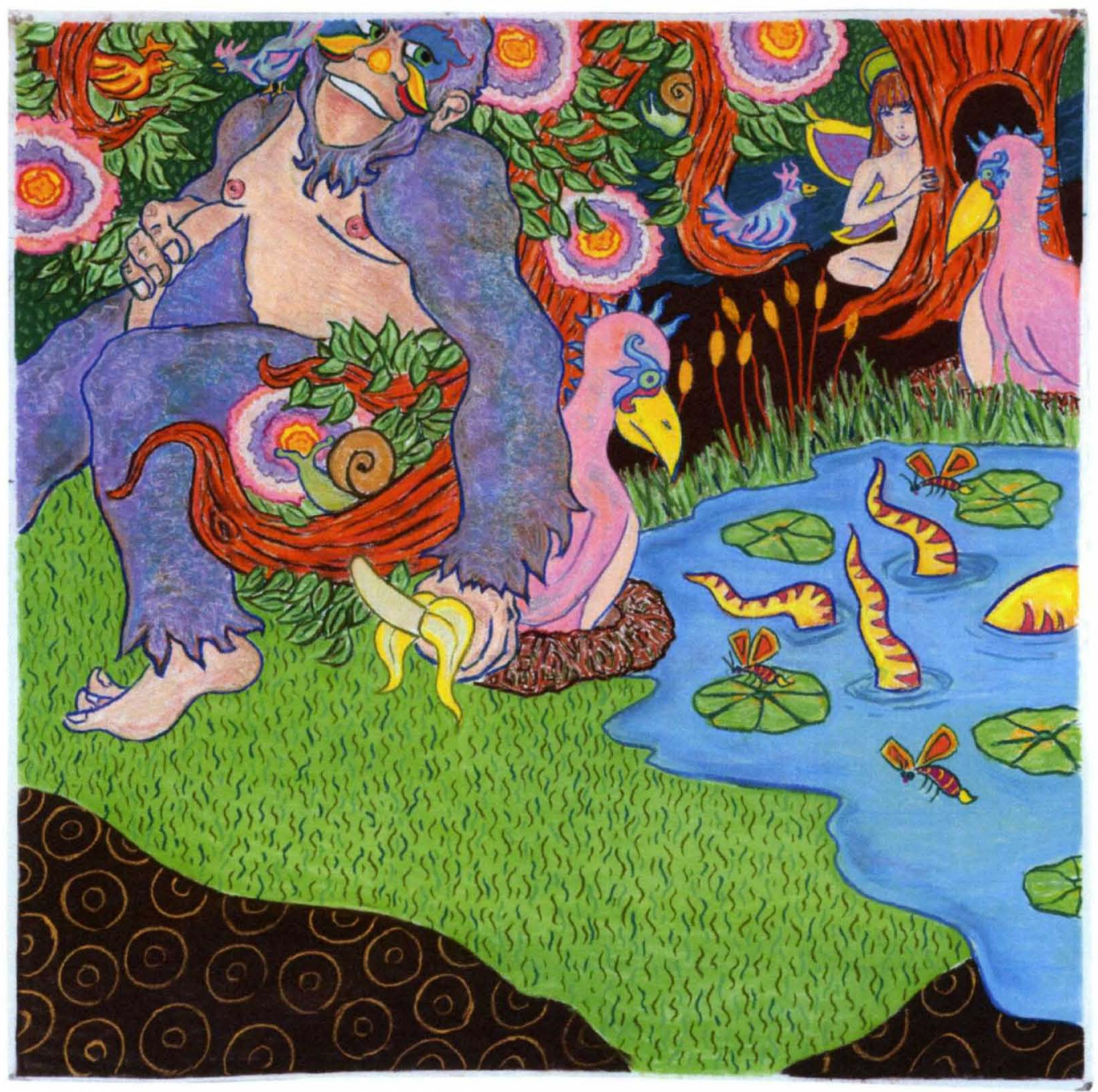

Figure 3. Chapter 1: The Jungle, Pastel on paper, 2010 


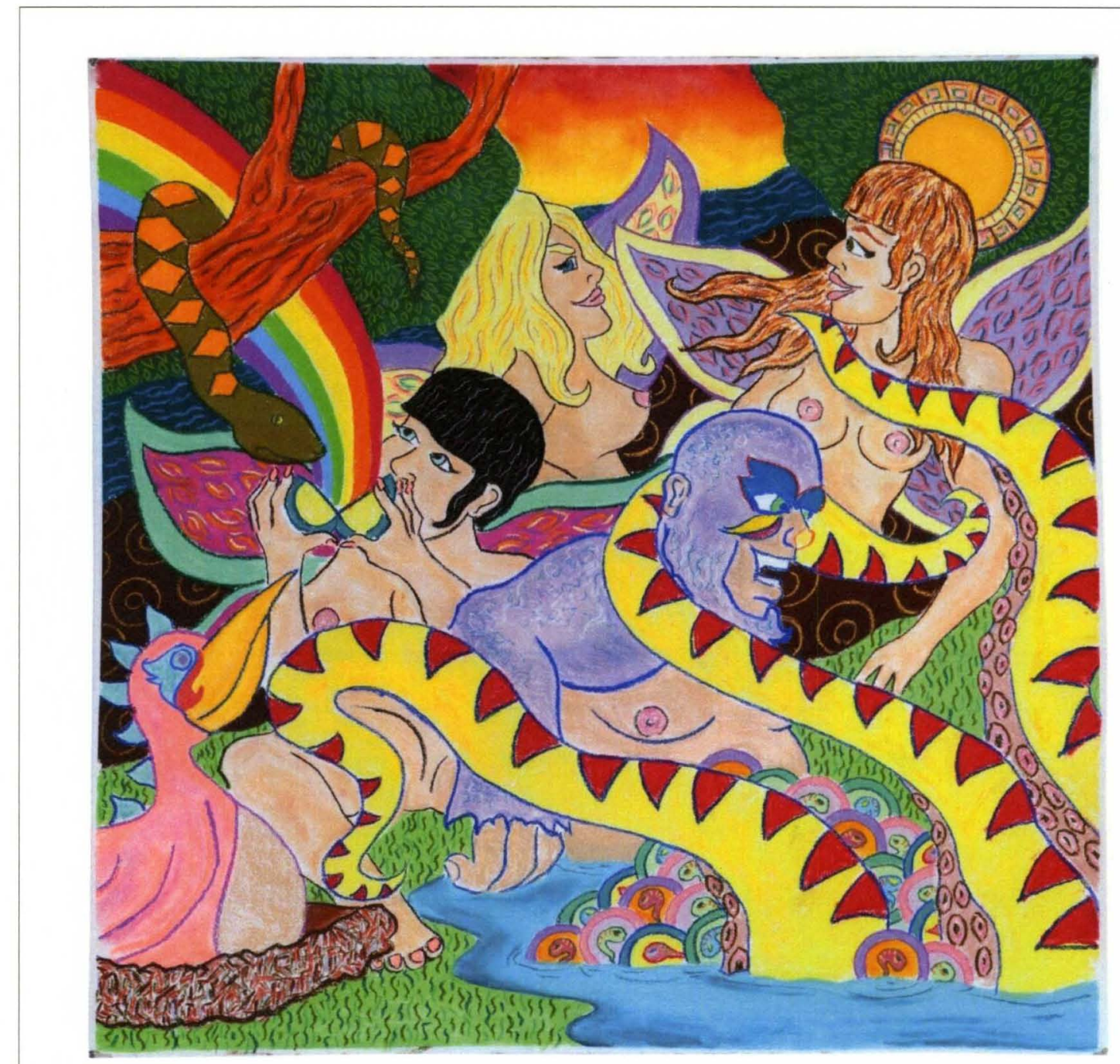

Figure 4. Chapter 2: The Rendezvous, Pastel and Paper, 2010 


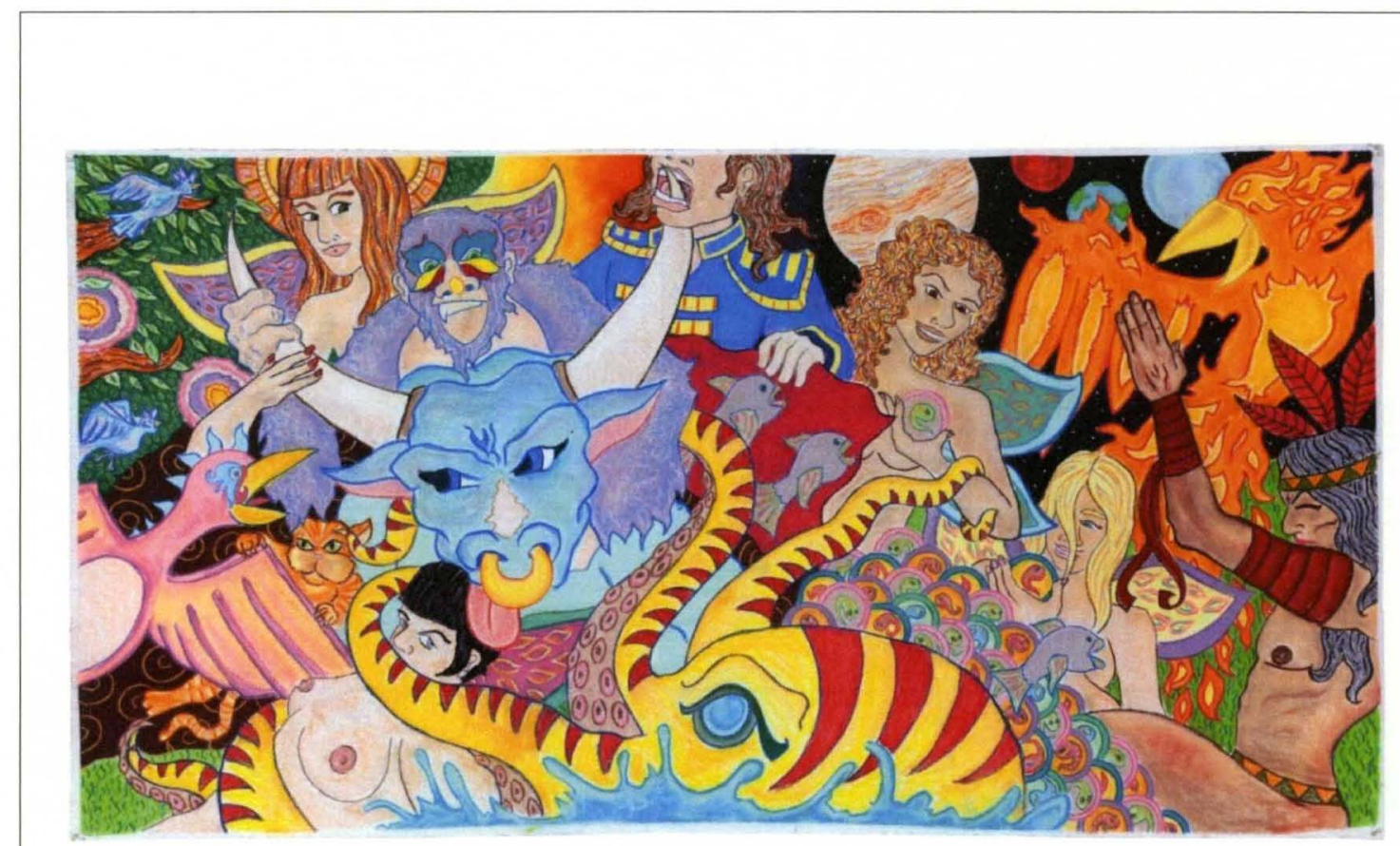

Figure 5. Chapter 3:The Explosion of Knowledge, Pastel on Paper, 2010 


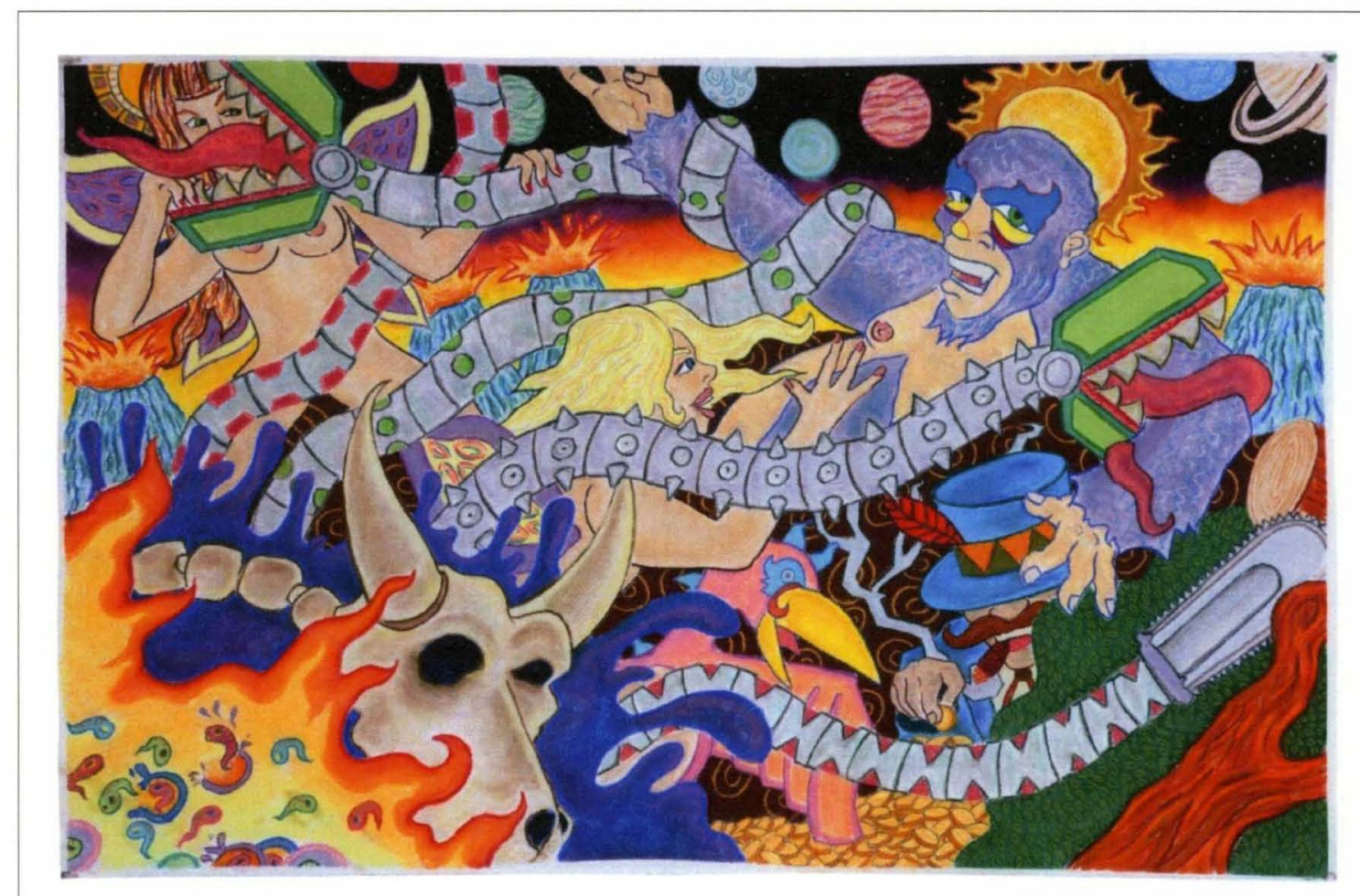

Figure 6. Chapter 4: The Expansion, Pastel on paper, 2010 


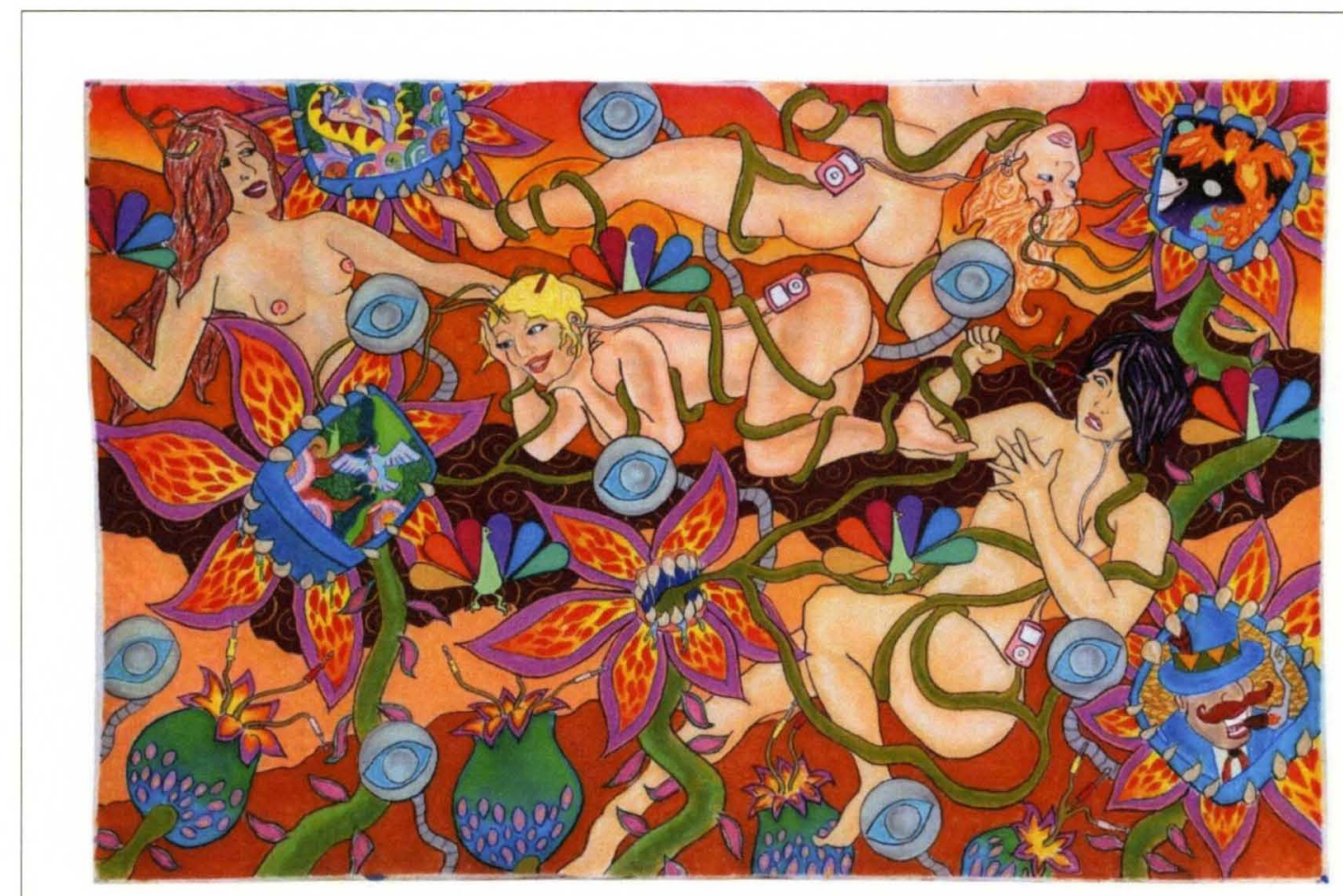

Figure 7. Chapter 5: The Brainwash, Pastel on Paper, 2010 


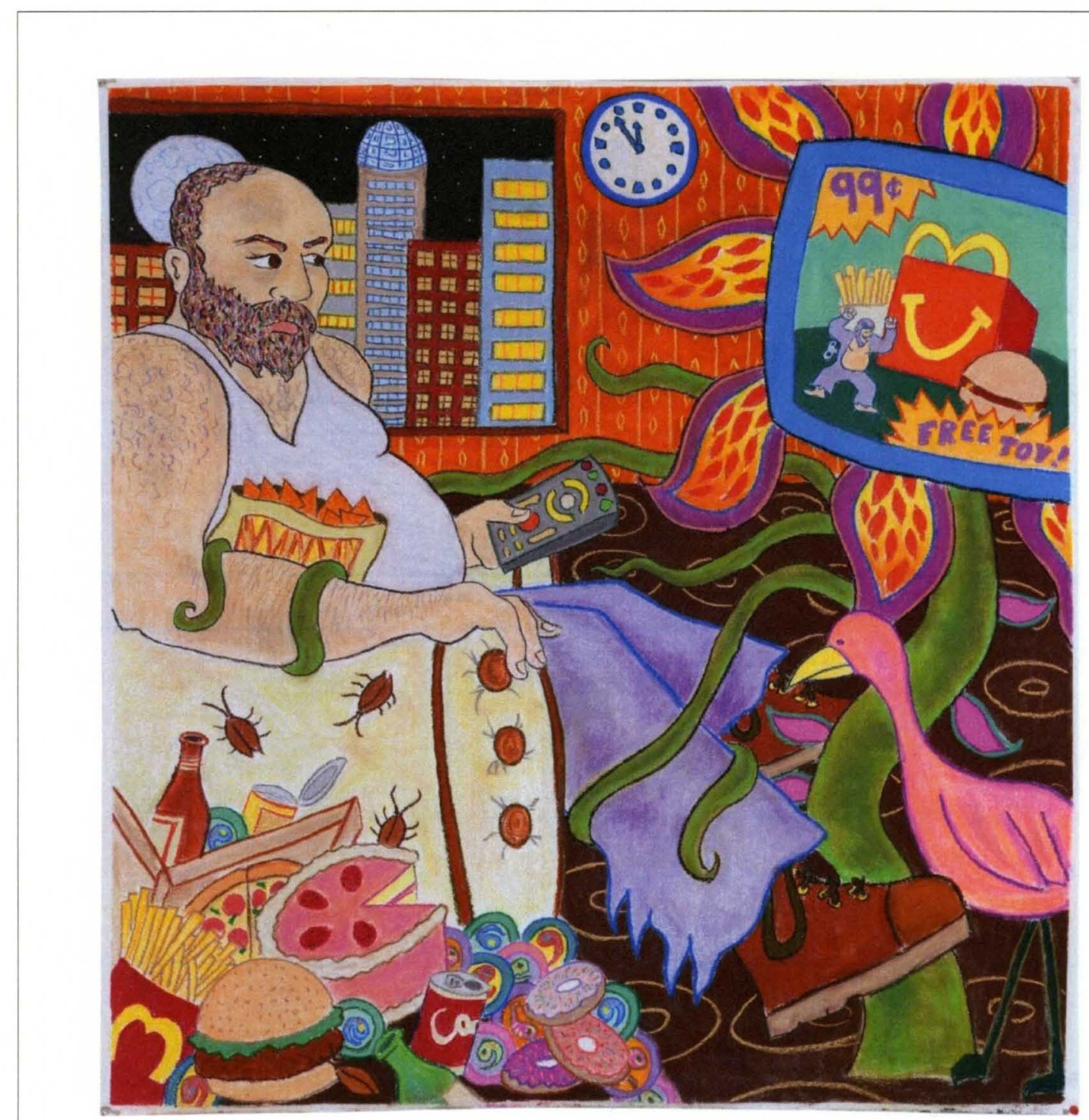

Figure 8. Chapter 6: The Acceptance, Pastel on paper, 2010 


\section{CURRICULUM VITAE}

NAME: $\quad$ Nick Karl

ADDRESS: $\quad 830 \mathrm{~W}$. Whitney Ave

Louisville, KY 40205

DOB: $\quad$ Louisville, KY - July 28, 1982

EDUCATION: M.A. Drawing

University of Louisville

2008-2010

B.F.A Drawing

University of Louisville

2002-2008

EXHIBITIONS:

Solo

2010, Solo Show, Maido: Essential Japanese Cuisine and Sake Bar, Louisville, KY

Bi-Person

2010, M.A. Thesis Exhibition, Cressman Center Gallery, Louisville, KY

Group

2007 B.F.A. Student Show, University of Louisville, Hite gallery, Louisville, KY

2008 Eudaimonia: Art as a Way of Life, Jefferson Community and Technical College, Louisville, KY, Group Exhibition

2008 B.F.A Thesis Exhibition, University of Louisville, Hite Gallery, Louisville, KY 2009 Juried Show, Rouge Noir, Rouge Noir Gallery, Louisville, KY

2009 Juried Show, Rouge Noir, Rouge Noir Gallery, Louisville, KY

2009, LEO Magazine, Image in Magazine, 12/02/09

2009, \$30 Art Show, Rouge Noir, Rouge Noir Gallery, Louisville, KY

2010, Solo Show, Maido: Essential Japanese Cuisine and Sake Bar, Louisville, KY

AWARDS:

Hite Scholarship, University of Louisville, 2007-2008, 2008-2009, 2009-2010 